\title{
Collisional collapse and accretion of late Paleozoic Akiyoshi seamount
}

The paleogeographic reconstruction of an oceanic-rock assemblage of the late Paleozoic accretionary Akiyoshi terrane in southwestern Japan is based on four coeval sedimentary units. These units consist of massive shallow-water limestone, redeposited limestone and spicular chert interbeds (both lying on greenstone), spicular chert and displaced limestone lenses, and radiolarian chert. which are interpreted to be the sediments on the top, the upper flank, and the lower flank to foot of a seamount, as well as the sediments on the surrounding ocean floor, respectively.

The limestone is pervasively disrupted internally to form extensive oligomictic broken limestone and a variety of polymictic limestone breccias, which are displaced largely onto terrigenous sediments. These rocks suggest a large-scale collapse of the seamount when it encountered a convergent margin.

\section{Introduction}

An oceanic-rock assemblage, typified by reefal limestones, spicular or radiolarian cherts, and basaltic lavas and volcaniclastic rocks. characterizes Japanese accretionary terranes of the late Paleozoic and Mesozoic. Together with terrigenous clastic rocks, the oceanic rocks form the heterogeneous and structurally complicated accretionary terranes that extensively underlie the Japanese islands. The Akiyoshi and Mino-Tamba terranes in southwestern Japan are representative examples (fig. 1). The origin and emplacement process of oceanic rocks are of great interest to those whose work involves the tectonic evolution of accretionary prisms.

We review here the depositional setting of the Carboniferous and Permian oceanic rocks of the Akiyoshi terrane by using a sedimentary model in which we reconstruct these rocks as sediments on and around a seamount in an open-ocean realm (Kanmera and Nishi. 1983; Sano and Kanmera, 1988; Kanmera and others, 1990). We also describe the extensive and diverse collapse products of limestones that were generated by the collisional disruption of the Akiyoshi seamount (Sano and Kanmera, 1991a-d).

\section{Stratigraphy of Akiyoshi terrane rocks}

Rocks of the Akiyoshi terrane, the oldest nonmetamorphic accretionary terrane of Japan, are exposed in several unconnected areas in southwestern Japan (fig. 1), and they are separated by fault zones

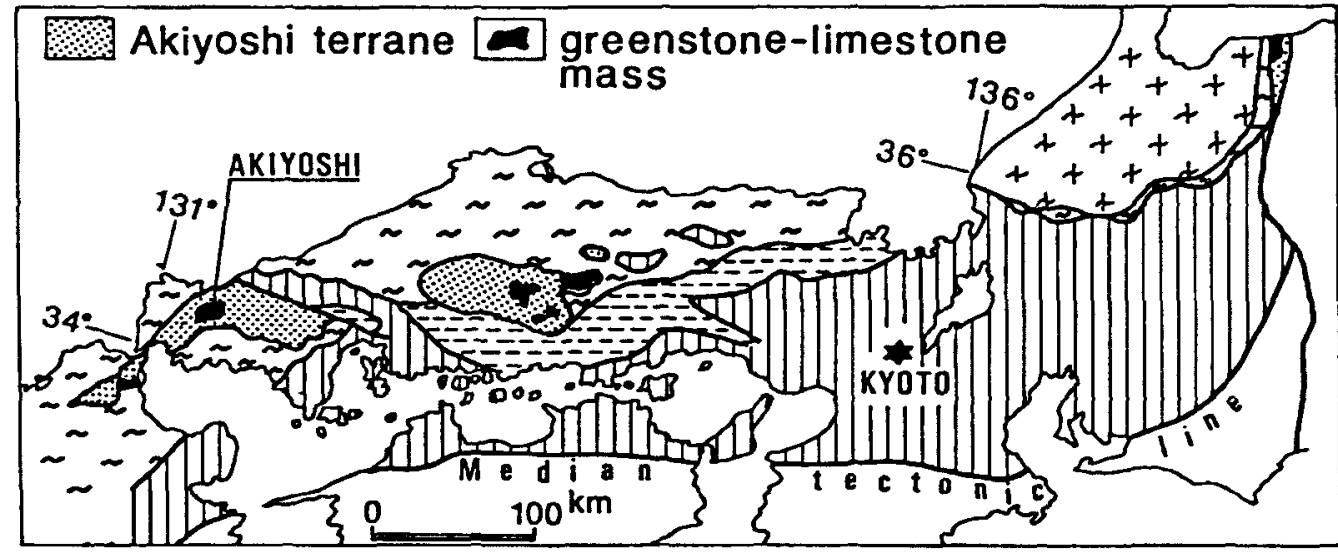

$t_{t}+$ Hida metamorphic terrane Maizuru terrane

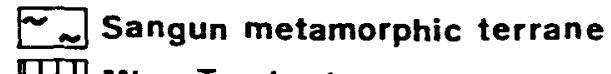

DID Mino-Tamba terrane
Figure 1.-Southwestern Japan showing the distribution of the Akiyoshi terrane and the location of representative greenstone-limestone masses, which are remnants of Carboniferous and Permian seamounts. 


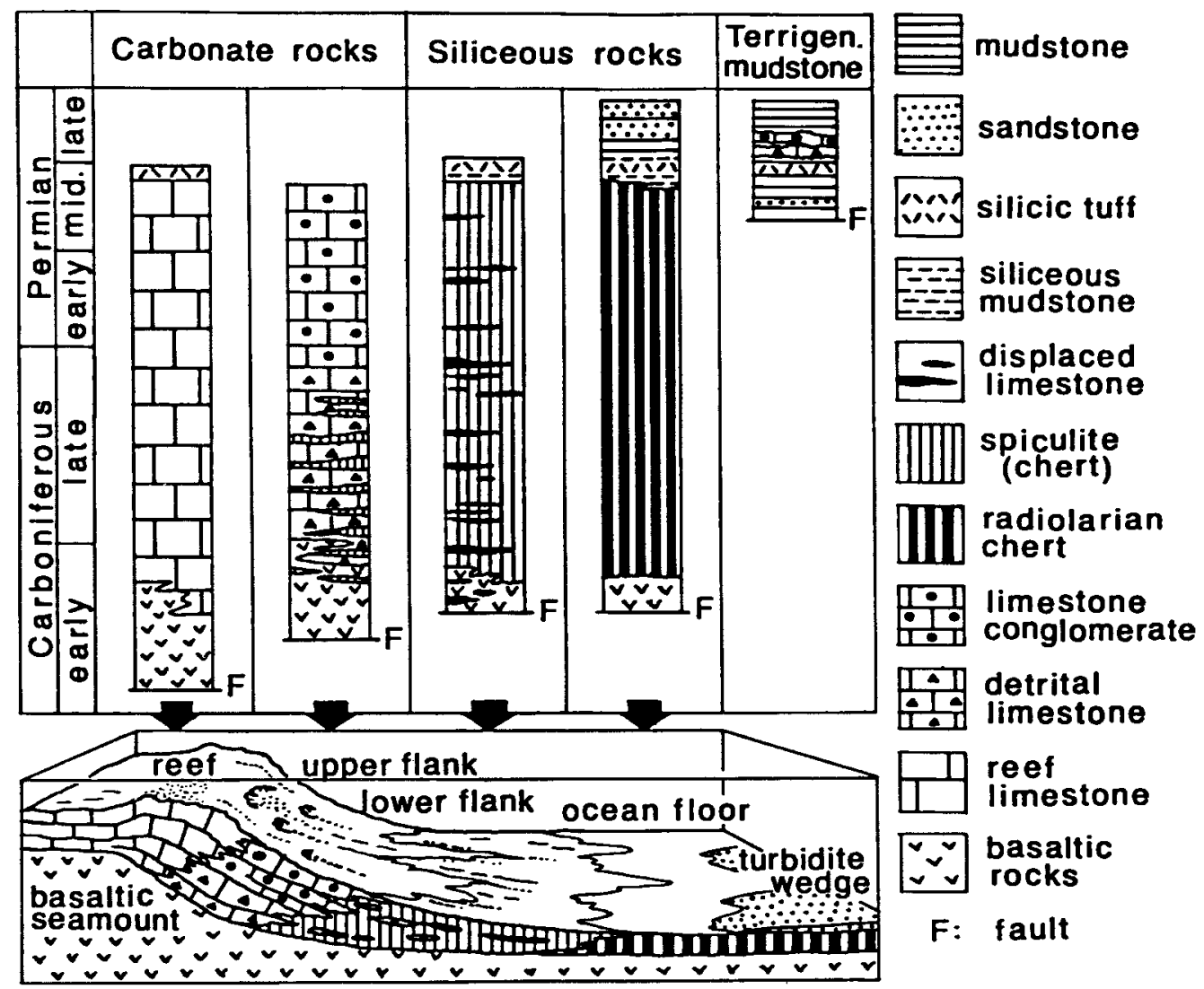

Figure 2.-Composite columnar sections summarizing the lithostratigraphy and age of Akiyoshi terrane rocks and the sedimentary-framework model for oceanic rocks. Modified from Sano and Kanmera (1988). Abbreviations: terrigen., terrigenous; mid., middle.

from the adjoining terranes. The Akiyoshi terrane is characterized by the existence of several large, isolated limestone masses (fig. 1), which are underlain by greenstones and are surrounded by noncalcarsous rocks, including cherts. The Akiyoshi Limestone Group is the largest of these limestone masses, and it also furnishes the best example of clear biostratigraphic zonation based on fusuline and other fossils, as well as on sedimentary petrologic analysis. The Akiyoshi terrane rocks, intensely deformed and sheared, are overlain unconformably by mainly nonmarine and only gently deformed Upper Triassic clastic rocks.

The Akiyoshi terrane rocks are grouped into three fault-bounded rock units - carbonate rocks, siliceous rocks, and terrigenous clastic rocks - each of which is reconstructed to have occupied the depositional setting shown in figure 2 (Sano and Kanmera, 1988).

\section{Carbonate rocks -Seamount-cap and seamount-flank sediments}

This unit is divided into two major facies, the main limestone facies (650-750 $\mathrm{m}$ thick) consisting of massive limestones and the marginal limestone facies $(600-650 \mathrm{~m})$ that is characterized by limestone conglomerates and interbeds of chert and cherty limestone (fig. 2). These limestones range in age from late early Carboniferous to late middle Permian (see Ota, 1977; Hase and others, 1974).

The main limestone facies (the Akiyoshi Limestone Group) is interpreted as an organic reef complex that formed in very shallow water. It includes mainly lime grainstones and lime wackestones that are rich in shallow-marine fossils. Coral-algal boundstone patches and oolitic grainstones are common in the Carboniferous section (see Ota, 1968; Nagai, 1985).

The Carboniferous section of the marginal limestone facies consists mainly of interbedded limestones and cherts. The limestones are mostly packstones made up of limestone fragments of varied rock types and fossil debris derived mainly from crinoids, bryozoa, and brachiopods (Hase and others, 1974). Siliceous sponge spicules replaced by calcite are common. The interbedded cherts consist chiefly of siliceous sponge spicules and are termed spiculite. The Permian section comprises limestone conglomerates that are composed of polymictic, disorganized, subangular to subrounded shallow-marine limestone clasts (fig. 2). These detrital limestones and limestone conglomerates are interpreted as forereef talus deposits, which were derived from the reef above the main limestone facies (Hase and others, 1974).

The limestone successions of the two facies conformably overlie a greenstone succession that is composed of basaltic volcaniclastic rocks (fig. 2) and some pillow lavas. In the greenstone section underlying the massive limestones, the lavas and volcanic breccias are highly vesicular. The uppermost part of the section consists of volcaniclastic sandstones and siltstones containing abundant debris of crinoids, brachiopods, and corals. These beds change going up the section into limestones with coralgal boundstones and oolites. These features indicate that the volcanic rocks underlying the massive limestones are the products of submarine eruptions that took place at 
shallow depths near sea level (Kanmera and Nishi, 1983). On the contrary, the volcanic rocks underlying the limestone conglomerates have no indication of eruptions at shallow-water depths, but they do have thin intercalations of chert and limestone debris. The greenstone successions are no more than $300 \mathrm{~m}$ thick, and their lower limits are bounded by faults.

In summary, the carbonate rocks represent an organic reef complex and forereef deposits that rest upon a basaltic pedestal in an open-ocean setting. The reef top reached very shallow water depths or even sea level.

\section{Siliceous rocks-Seamount-foot to ocean-floor sediments}

The siliceous-rock unit begins with basaltic volcaniclastic rocks (less than $30 \mathrm{~m}$ thick) and is followed by cherts $(60-100 \mathrm{~m})$ and siliceous mudstones $(20-70 \mathrm{~m})$ that are accompanied by silicic tuffs derived from airborne tephra (fig. 2). This succession is overlain by a thick terrigenous-rock section of mudstone and sandstone (up to $500 \mathrm{~m}$ ).

The siliceous-rock section ranges in age from latest early Carboniferous to late middle Permian (Uchiyama and others, 1986; Goto, 1988; Oho and others, 1985). The lower part of the terrigenous-rock section yields radiolaria of late middle to earliest Late Permian age (Sano and others, 1987). The siliceous-rock section is, therefore, nearly coeval with the carbonate successions described above. The lower limit of this unit is also bounded by faults.

Two lithologic varieties of chert are differentiated in this unit: spiculite that is crowded with siliceous sponge spicules and scarce radiolaria and radiolarian chert in which radiolaria dominate over sponge spicules (fig. 2). Unlike the radiolarian chert section, the spiculite section is characterized at many levels by lenses that consist of limestone debris of varied rock types and by lime wackestones and lime packstones that contain shallow-water fossils and have redeposited fabrics. The limestone lenses are invariably enclosed within siliceous limestone that is composed of a mixture of calcitic skeletal fragments and siliceous mud containing siliceous sponge spicules. This mixture resulted from a combination of unconsolidated calcareous and siliceous sediments (Kanmera and Nishi, 1983; Sano and others, 1987). These features indicate that unconsolidated carbonate sediments or lithified limestones or both were displaced by gravityinduced flows of sediment from a nearby carbonate buildup (that is, the Akiyoshi seamount) that reached from shallow-water depths into a deeper basin of spiculite deposition. In contrast, the radiolarian chert section, which has no displaced limestones lenses, is made up of sediments that were deposited at a greater distance from the carbonate buildup.

The siliceous mudstones overlying the cherts are characterized by a gradual increase in the amount of clay minerals going up the section and are succeeded by terrigenous rocks interpreted to be a tapering wedge of trench-filling turbidites (Kanmera and others, 1990). This unit represents oceanic to trench stratigraphy of Carboniferous to Permian age.

\section{Terrigenous mudstones and redeposited carbonates-Trench sediments containing collapsed seamount material}

This unit consists mainly of mudstones accompanied by lenses of detrital limestone, limestone conglomerates, silicic tuffs, and sandstones (fig. 2). The mudstones yield radiolaria of late middle to earliest Late Permian age (Sano and others, 1987).

The mudstones commonly have thin sandstone layers that often show graded bedding. Wet-sediment deformation resulting from the flow of sandy beds is common. The mudstones are severely deformed and have been converted into slate. Thin silicic tuff beds are, at places, intercalated in the mudstones. The silicic tuffs are usually light greenish, are extremely fine grained, and locally contain radiolaria.

The detrital limestone breccias comprise angular to subangular. unsorted, polymitic limestone clasts of late Carboniferous to late middle Permian age and fragmented fusuline individuals of late middle Permian age, which are densely packed and have a little mudstone matrix. The limestone conglomerates comprise subrounded to rounded, fairly well sorted clasts of the same ages. The limy sandstones consist of fine-grained, abraded limestone debris and terrigenous quartz and feldspar and mudstone chips. They are usually well sorted and occasionally graded, and they change laterally into mudstones. Isolated limestone blocks and debris, as well as fusuline individuals, are scattered in the mudstones near these limestone breccias, conglomerates, and sandstone.

These redeposited limestones are the displaced products that resulted from the disruption and collapse of the carbonate-rock unit (Kanmera and Nishi, 1983; Kanmera and others, 1990), and they are related intimately to the limestone breccias in the marginal part of the Akiyoshi limestone plateau, described later.

\section{Reconstruction of depositional setting of Akiyoshi oceanic rocks}

Important points for the paleogeographic reconstruction of the Akiyoshi oceanic rocks are (1) the total absence of terrigenous materials in the oceanic-rock successions, (2) the contemporaneity of the carbonate- and siliceous-rock successions, both resting upon basaltic rocks and both covered by silicic tuffs containing radiolaria indicative of the same age, and (3) the lateral links between the massive limestone succession and the radiolarian chert succession through the detrital limestone succession containing spicular chert interbeds and the spicular chert succession containing displaced limestone lenses. These are coeval and closely related lithologically.

All lines of stratigraphic, paleontological. and sedimentological evidence lead us to a sedimentary model for the Akiyoshi oceanic rocks (fig. 2). The four coeval rock units pass laterally from one to another and represent sediments on and around a seamount in an open-ocean realm. The reef limestones, the detrital limestones containing spiculite interbeds, the spiculites containing displaced limestones, and the radiolarian cherts are interpreted to be the sediments on the top, the upper flank, and the lower flank to foot of the Akiyoshi seamount, as well as the sediments on the surrounding ocean floor, respectively. The spiculites represent a proximal facies of the radiolarian chert. The stratigraphy of the radiolarian chert through the terrigenous clastic rocks implies the migration of its depositional site from an open-ocean realm to a convergent margin that supplied terrigenous detritus and tephra.

\section{Limestone breccias record seamount collapse}

We have found large-scale limestone breccias in the Akiyoshi limestone plateau (fig. 1), which is underlain entirely by the main limestone facies (Akiyoshi Limestone Group). The breccias provide 
us a significant key to understanding the collisional events of the organic reef-capped Akiyoshi seamount (Sano and Kanmera, 1991a-d).

We have recognized three varieties of limestone breccias: broken limestone, limestone breccia that has a carbonate matrix, and limestone breccia that has an argillaceous matrix. The first two are collapse breccias that were formed in place to nearly in place as a result of internal mechanical disruption of the parent limestones. The third breccia is a displaced collapse breccia and marks a depositional progression to limestone conglomerates and limy sandstones in the terrigenous rocks (Sano and Kanmera, 1991c).

\section{Broken limestone}

The broken limestone of the Akiyoshi terrane is seemingly massive and homogeneous, hardly distinguishable from ordinary massive bioclastic limestone in the field. However, thin-section examination of fusulines based on closely spaced sampling indicates that an orderly biostratigraphic succession is not present. Instead, we find an internal structural heterogeneity that is represented by the disordered distribution of fusuline assemblages. The limestone body is disrupted internally into blocks and breccias of various dimensions.

In thin sections and polished slabs, the broken limestones exhibit penetratively disrupted structures that consist of aggregates of brecciated fragments ranging from $2 \mathrm{~mm}$ to several tens of centimeters across. A complicated network of interstices is filled with comminuted particles (smaller than $2 \mathrm{~mm}$ ) (fig. 3). The rock fragments are angular and irregularly shaped and have been, at most, only slightly displaced from their original positions, so they often have clearly matching boundaries. No exotic components are admixed. Therefore, even fragmented fusulines are suitable for age determination where the disruption is weak. We should stress that the distupted products are not contorted or deformed in a ductile manner.

On the basis of the oligomictic association, the high angularity, and the excellently fitting boundaries of the rock fragments of the broken limestone, we interpret the parent rocks to have been disrupted internally in a brittle manner.

\section{Limestone breccia with a carbonate matrix}

This type of limestone breccia is composed of angular polymictic limestone clasts of various rock types and different ages, isolated skeletal fragments, and a fine-grained carbonate matrix. It is differentiated from the broken limestone in its polymictic clast association. The polymictic nature is indicated by fusulines of different ages that are contained in the clasts, the youngest of which is of late middle Permian age.

The clasts are a few millimeters to a few meters across and are most commonly a few tens to several tens of centimeters across. They tend to be larger (more than a few meters across) in places where this type of limestone breccia is present contiguously or repeatedly with the broken limestone. They are invariably angular and irregular in shape and are unsorted (fig, 4A). The matrix is variable in amount and consists of fine-grained, disrupted particles and some skeletal fragments and calcite chips that were derived from primary sparry calcite cement.

The polymictic nature of this type of limestone breccia reveals a notable dislocation and mixing of the disrupted rock pieces or clasts. The close similarity in rock fabrics and the lithologic affiliation of clasts between this type of limestone breccia and the broken limestone imply their genetic kinship and the derivation of the clasts from the broken limestone.

\section{Limestone breccia with an argillaceous matrix}

This type of limestone breccia is characterized by the presence of a terrigenous-mud matrix and by the reworked nature of the clasts; hence, it is discriminated from the broken limestone and the limestone breccia with a carbonate matrix. The clasts are angular to subangular and polymictic, and they are mixed with small amounts of isolated fossil fragments, mostly fusulines, and a terrigenous-mud matrix (fig. 4B). The rock types of the clasts are almost identical to those of the limestone breccia that has a carbonate matrix, and the most predominant clasts are of late to latest middle Permian age.

Some of the muddy limestone breccia that is found in the marginal part of the Akiyoshi limestone plateau passes laterally into limestone breccias and then into limestone conglomerates of the terrigenous-mudstone unit.

The microscopic characteristics of the muddy limestone breccia indicate that it was formed by the displacement and coincident depositional mixing of the disrupted limestones by gravity-induced sediment flows, including debris flows. The limestone breccia of this type and the limestone conglomerates and limy sandstones of the terrigenous-mudstone unit are interpreted to have formed a depositional progression ranging from debris-flow deposits represented by these limestone breccias at one extreme to turbidites represented by limy sandstones at the other.

\section{Distribution and age of limestone-breccia rocks}

Thin-section examination reveals that the broken limestone is widespread over almost the whole area of the Akiyoshi limestone plateau (Sano and Kanmera, 1991d). The distribution of the broken limestone is not related to faulting. These facts imply that the parent Akiyoshi Limestone was pervasively and penetratively disrupted to form the broken limestone. The limestone breccias of the two types crop out only in areas where the Akiyoshi Limestone Group tectonically overlies the terrigenous-mudstone unit, that is, the marginal areas of the western Akiyoshi plateau.

The age of the Akiyoshi breccia rocks is determined by means of fusuline fossils embedded in the rock fragments or clasts. The broken limestone spans almost the whole time range of the Akiyoshi Limestone Group, late early Carboniferous (Visean) to latest middle Permian (Sano and Kanmera, 1991d). The minimal age of the limestone breccias is late middle Permian.

\section{Collapse of Akiyoshi seamount}

Emphasizing the pervasive internal brittle disruption of the Akiyoshi Limestone, we have proposed a hypothesis to explain the tectonic events during the collision of the Akiyoshi seamount along a convergent margin (Sano and Kanmera, 1991d). Behind our hypothesis is the geophysical and geomorphological information on the DaiichiKashima Seamount, a modern analog that is being subducted and at the same time broken by normal faults in the Japan Trench (see Kobayashi and others, 1987).

The postulated sequence is summarized as follows (fig. 5). (1) Encroachment of the Akiyoshi seamount into a trench area was accompanied by rifting along normal faults in the outer trench slope (fig. 5A); (2) generation of the fault-induced network of fractures in the fault-split and trenchward-tilted blocks (fig. 5B); (3) large-scale collapse of the seamount and associated internal disruption of the collapsed bodies by their own overloading, which resulted in the formation of broken limestone (fig. 5C); (4) mixing of the disrupted products within the collapsed wedge moving downslope and forma- 
tion of limestone breccia that has a carbonate matrix (fig. 5C); and (5) displacement of the collapse products by gravity-induced sediment flows from the wedge onto trench-filling terrigenous sediments represented by mudstones, as well as formation of limestone breccia that has an argillaceous matrix by depositional mixing of the collapse products, coincident with subsequent redeposition of limestone conglomerates and limy sandstones (fig. 5C, D).

The collapse products were offscraped and incorporated into an accretionary prism together with trench sediments (fig. 5D). The collisional collapse is considered to have happened within a short time, as indicated by the age of the mudstones containing the collapsed limestones, which ranges from the late middle to earliest Late Permian.

\section{Summary}

Sedimentary evolution during Carboniferous and Permian time in an open-ocean realm is recorded in the stratigraphy of accreted oceanic rocks in the Akiyoshi terrane of southwestern Japan. The oceanic
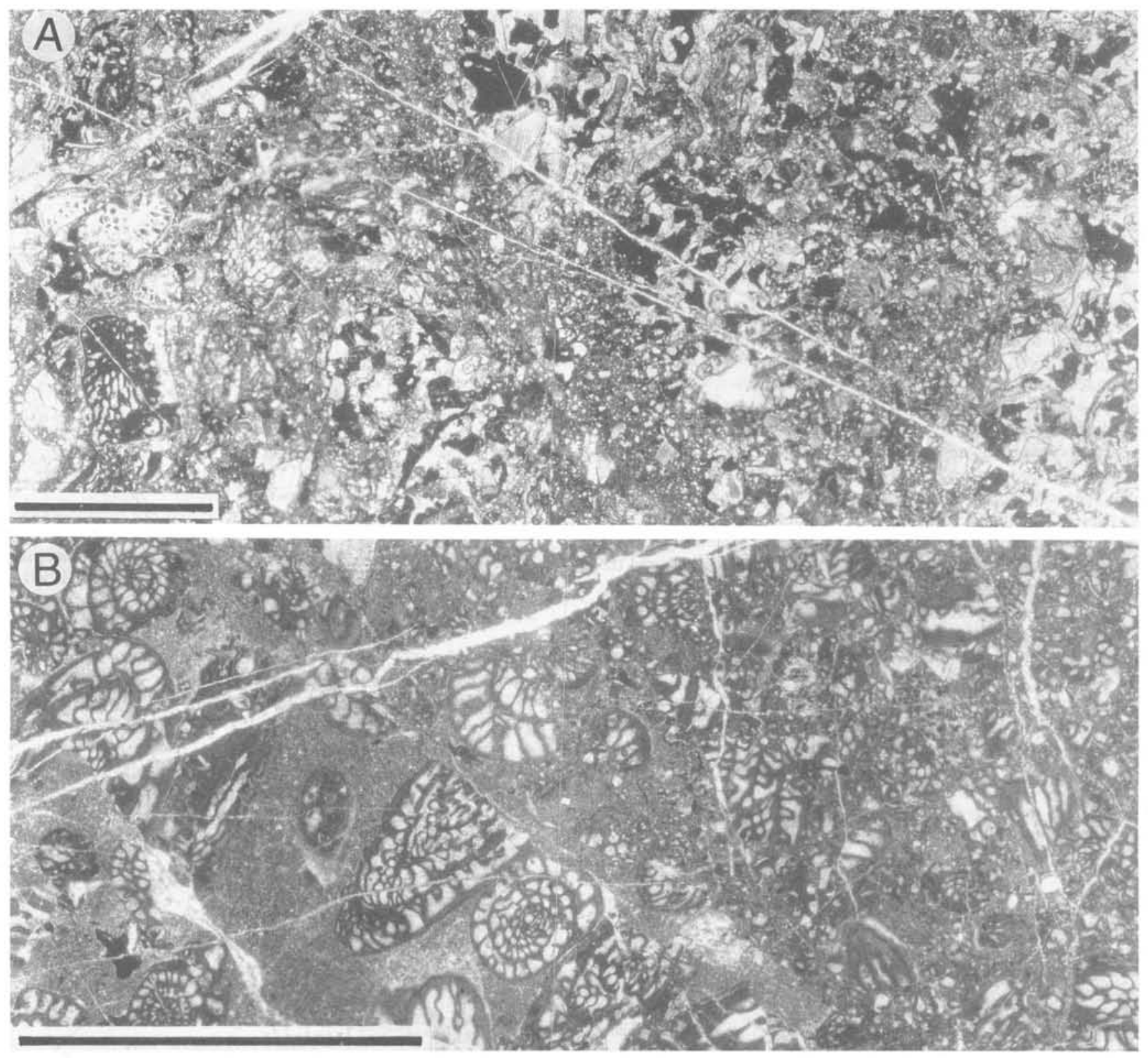

Figure 3.-Thin-section photomicrographs of broken limestones. A, Moderately broken lime grainstone. Primary Tubiphytes-rich grainstone that has sparry calcite cement has been disrupted into variously sized and irregularly shaped fragments and matrix-forming sand- to clay-sized comminuted particles. Note no contortion, elongation, or shortening of fragments. B, Weakly to moderately broken fusuline lime mudstone. Lower left is almost unbroken, but upper right is intensely disrupted. Note that the lime-mud matrix in the broken part contains many comminuted particles. Scale bars are $5 \mathrm{~mm}$. 


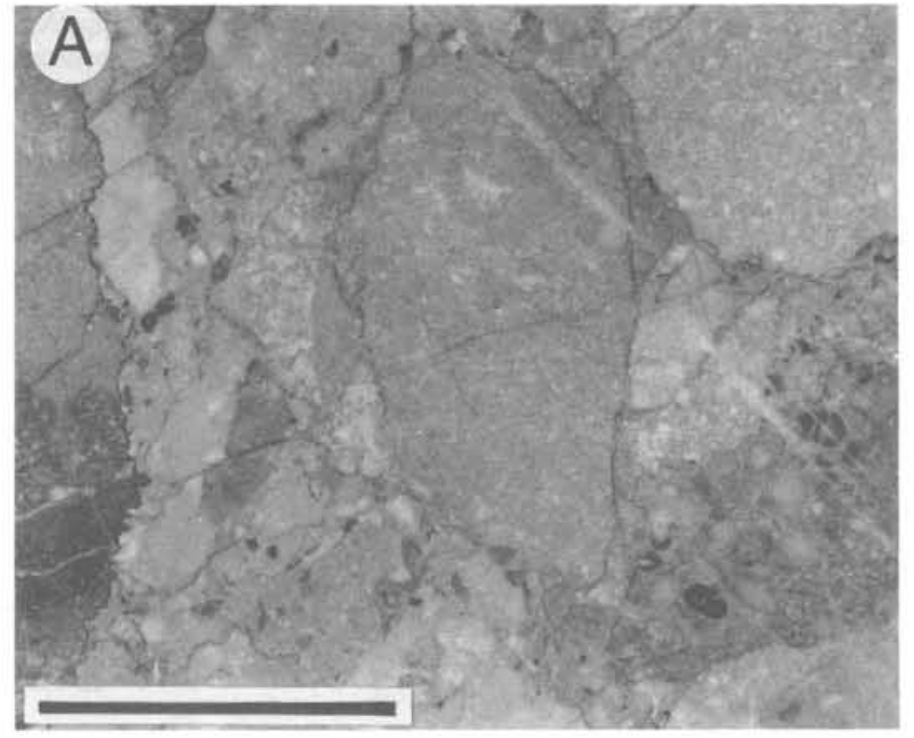

Figure 4.-Examples of two varieties of limestone breccias. A, Polished slab of limestone breccia that has a very sparse carbonate matrix comprising unsorted, angular, polymictic, and densely packed limestone clasts. It shows a diagenetic packstone fabric and stylolite-sutured contacts. Scale bar is $5 \mathrm{~cm}$.

rocks are reconstructed as extensive continuous masses ranging from a shallow-water reef complex on a basalt-based seamount to deepwater siliceous sediments on the ocean floor around the seamount. The gradual vertical change from the siliceous rocks to the overlying terrigenous clastic rocks indicates the migration of depositional sites from an open-ocean realm to a trench area. Microscopic deformation fabrics of the limestones document collisional events of the seamount, in which large-scale collapse of the reef complex, probably induced by normal faulting in the outer trench-slope area, played the most important roll. The collapse has resulted in the generation of extensive disrupted products, broken limestone and limestone breccias, of which the broken limestone covers almost the entire extent and almost the whole succession of the Akiyoshi Limestone Group.

\section{Acknowledgments}

We sincerely thank Dr. C.A. Landis (Otago, New Zealand), who kindly much improved the early version of the manuscript.

\section{References}

Goto, N., 1988, Stratigraphy of Permian siliceous-argillaceous rocks and their tectonic relation with coarse-grained clastics in Taishaku area, Southwest Japan: Journal of the Geological Society of Japan, v. 94, p. 501-514. [In Japanese, English abstract.]

Hase, A., Okimura, Y., and Yokoyama, T., 1974, The Upper Paleozoic formations in and around Taishaku-dai, Chugoku massif, Southwest Japan, with special reference to the sedimentary facies of limestones: Geological Reports of Hiroshima University, no. 19, p. 1-39. [In Japanese, English abstract.]

Kanmera, K., and Nishi, H., 1983, Accreted oceanic reef complex in Southwest Japan, in Hashimto, M., and Uyeda, S., eds., Accretion tectonics in the circum-Pacific regions: Tokyo, Terra Scientific Publishing Company, p. 195-206.

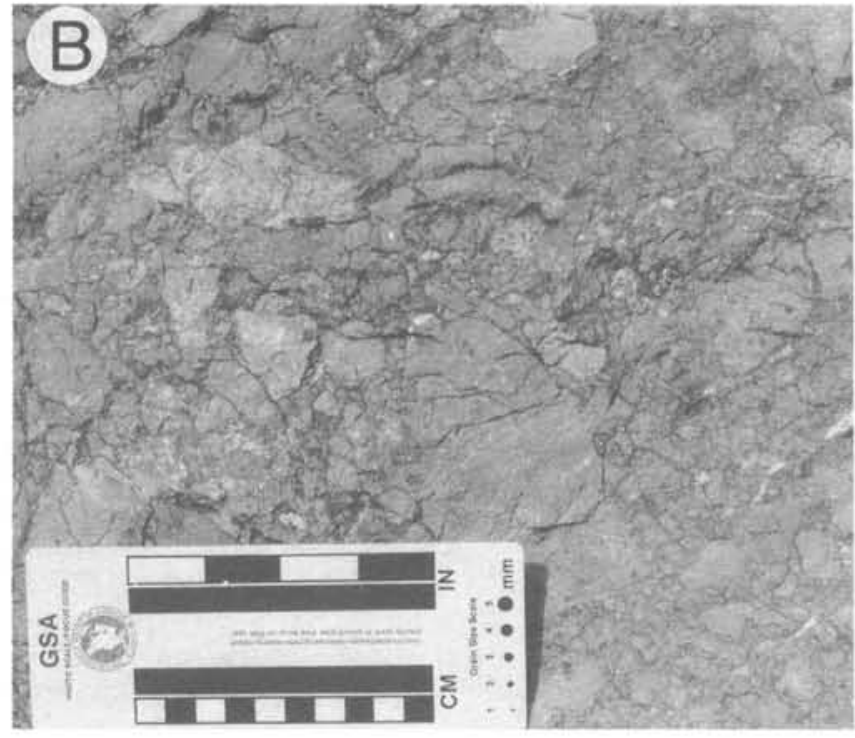

B, Closeup view of outcrop of limestone breccia that has an argillaceous matrix. In this breccia, angular, polymictic limestone clasts are densely packed and have a sparse terrigenousmud matrix.
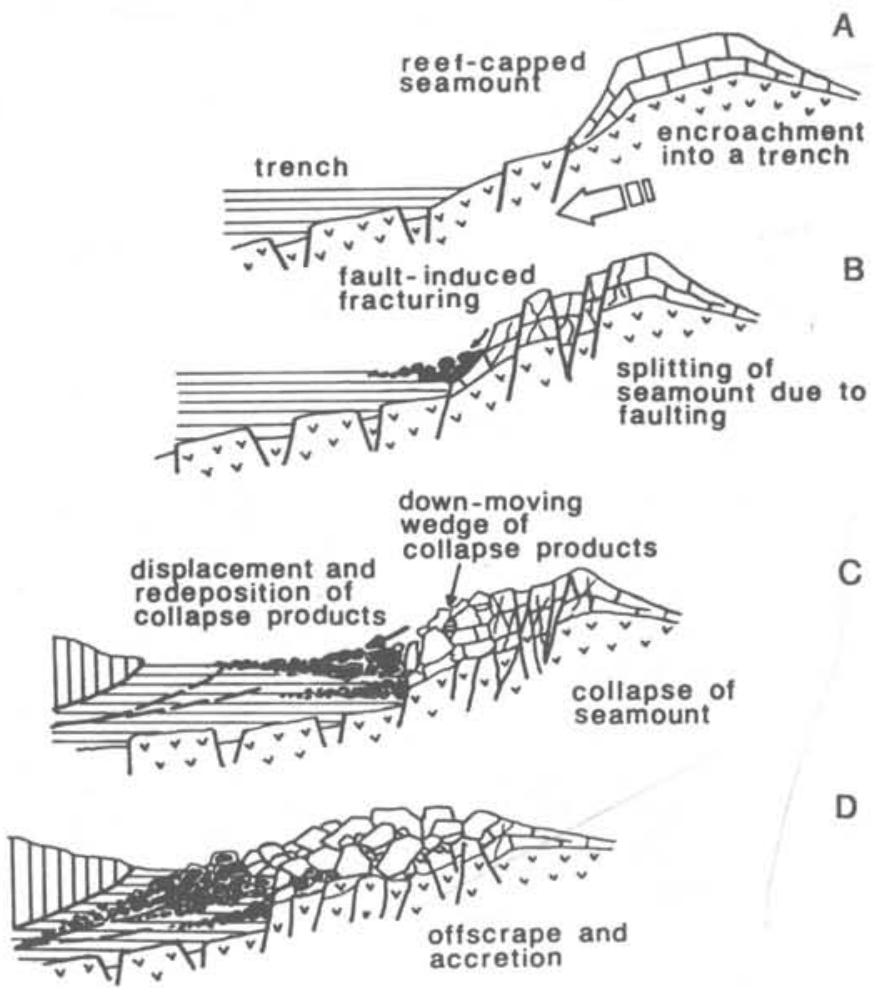

D

Figure 5.-Schematic diagrams illustrating the sequence of tectonic events during the collision and accretion of Akiyoshi seamount. Simplified from Sano and Kanmera (1991d). 
Kanmera, K., Sano, H., and Isozaki, Y., 1990, Akiyoshi terrane, in Ichikawa, K., Mizutani, S., Hara, I., Hada, S., and Yao, A., eds., Pre-Cretaceous terranes of Japan: Osaka, Japan, Osaka City University, Publication of International Geological Correlation Programme Project 224 , p. 49-62.

Kobayashi, K., Cadet, J.P., and others, 1987, Normal faulting of the Daiichi-Kashima Seamount in the Japan Trench revealed by the Kaiko 1 cruise, Leg 3: Earth and Planetary Science Letters, v. 83, p. $257-266$.

Nagai, K., 1985, Reef-forming algal-chaetetoid boundstone found in the Akiyoshi Limestone Group, Southwest Japan: Bulletin of Akiyoshi-dai Museum, Natural History, no. 20, p. 1-15.

Oho, Y., Inoue, M., and Sada, K., 1985, Stratigraphy and structure of the Carboniferous and Permian in the Yuki area of Hiroshima Prefecture, Southwest Japan: Journal of the Geological Society of Japan, v. 91, p. 771-778. [In Japanese, English abstract.]

Ota, M., 1968. The Akiyoshi Limestone Group; a geosynclinal organic reef complex: Bulletin of Akiyoshi-dai Science Museum, no. 5, p. 1-44. [In Japanese, English abstract.]

1977. Geological studies of Akiyoshi, part 1; general geology of the Akiyoshi Limestone Group: Bulletin of Akiyoshi-dai Museum, Natural History, no. 12, p. 1-33.

Sano, H., Iijima, Y., and Hattori, H., 1987, Stratigraphy of the Paleozoic rocks in the Akiyoshi terrane of the central Chugoku Massif: Journal of the Geological Society of Japan, v. 93, p. 865-880. [In Japanese, English abstract.]

Sano, H., and Kanmera, K., 1988, Paleogeographic reconstruction of accreted oceanic rocks, Akiyoshi, Southwest Japan: Geology, v. 16, p. $600-603$.

1991a, Collapse of ancient oceanic reef complex-What happened during collision of Akiyoshi reef complex? Geologic setting and age of Akiyoshi terrane rocks on western Akiyoshi-dai plateau: Journal of the Geological Society of Japan, v. 97, p. 113-133.

$-1991 \mathrm{~b}$, Collapse of ancient oceanic reef complex - What happened during collision of Akiyoshi reef complex? Broken limestone as collapse product: Journal of the Geological Society of Japan, v. 97, p. 217-229.

$-1991 c$, Collapse of ancient oceanic reef complex - What happened during collision of Akiyoshi reef complex? Limestone breccias, redeposited limestone debris, and mudstone injections: Journal of the Geological Society of Japan, v. 97, p. 297-309.

1991d, Collapse of ancient oceanic reef complex-What happened during collision of Akiyoshi reef complex? Sequence of collisional collapse and generation of collapse products: Journal of the Geological Society of Japan, v. 97, p. 631-644.

Uchiyama, T., Sano, H., and Kanmera, K., 1986, Depositional and tectonic setting of cherts around the Akiyoshi Limestone Group, Southwest Japan: Memoirs of the Faculty of Science, Kyushu University, series D, Geology, v. 26, p. 51-68.

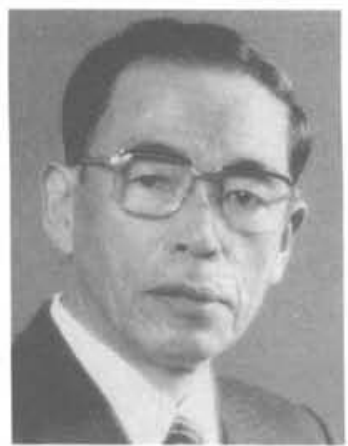

Dr. Kametoshi Kanmera is a Professor Emeritus of Kyushu University (Hakozaki, Fukuoka 812, Japan), where he worked at the Department of Geology for 40 years until his re. tirement in 1987. His major work was on Carboniferous and Permian biostratigraphy and paleontology that are based mainly on fusuline fossils, and over the last 15 years, his research interests have focused on the paleogeographic reconstruction of strongly disrupted and intermixed rock bodies in late Paleozoic and Mesozoic accretionary terranes of southwestern Japan.

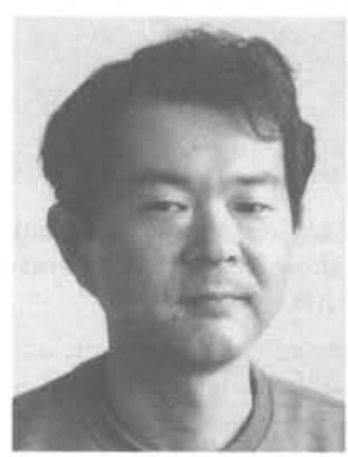

Dr. Hiroyoshi Sano graduated from the Department of Geology (since 1990, the Department of Earth and Planetary Sciences) of Kyushu University in 1975 and received his doctorate from the same university by studying the sedimentary petrology of bedded cherts in Paleozoic and Mesozoic accretionary prisms. From 1990 to 1991, he studied at four institutes of Academia Sinica as a visiting researcher doing stratigraphic and sedimentary petrologic work on Permian carbonate rocks of southern China. His recent interests focus on the late Paleozoic and Mesozoic tectonic evolution of eastern Asia and on the sedimentary environments of eastern Panthalassa during Permian time. 